\title{
MESOPOROUS SILICA MODIFIED WITH AMINO GROUP (NH2-MCM-48) AS ADSORBENT OF Ag(I) AND Cr(III) IN WATER
}

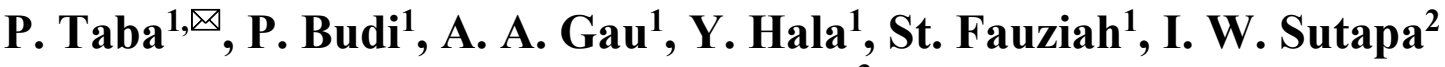 \\ and J. Manga ${ }^{3}$ \\ ${ }^{1}$ Department of Chemistry, Faculty of Mathematics and Natural Sciences, \\ Hasanuddin University, Makassar-90245, Indonesia \\ ${ }^{2}$ Department of Chemistry, Faculty of Mathematics and Natural Sciences, \\ Pattimura University, Ambon-97233, Indonesia \\ ${ }^{3}$ Department of Chemical Engineering, Politeknik Negeri Ujung Pandang, \\ Makassar-90245, Indonesia \\ ${ }^{\circledR}$ Corresponding Author: paulinataba@unhas.ac.id
}

\begin{abstract}
The amino-modified mesoporous silica $\left(\mathrm{NH}_{2}-\mathrm{MCM}-48\right)$ was synthesized using a mixture of surfactants as a template that was re-extracted using a methanol-hydrochloride solution. The modifying agent was 3aminopropyltrimethoxysilane (3-APTMS). The characterization was conducted using an X-ray diffractometer (XRD), Fourier Transform Infrared (FTIR) spectroscopy, and Scanning Electron Microscopy (SEM). We investigated the reduction of $\operatorname{Ag}(\mathrm{I})$ and $\mathrm{Cr}$ (III) concentrations in the solutions using the modified material under several variables, i.e., $\mathrm{pH}$, contact time, and initial ion concentration. An atomic absorption spectrophotometer measured the concentrations of the ions. The XRD and FTIR results proved that the basic material was MCM-48, and the template was mostly removed after the extraction, respectively. The modified material was successfully produced showed by the FTIR peak of $\mathrm{N}-\mathrm{H}$ stretching vibration. The equilibrium of the $\mathrm{Cr}$ (III) adsorption was achieved in a longer time than that of the $\operatorname{Ag}(\mathrm{I})$ adsorption. The adsorption kinetics of $\operatorname{Ag}(\mathrm{I})$ and $\mathrm{Cr}(\mathrm{III})$ ions obeyed a model of pseudo-second-order and followed better the Langmuir adsorption model than the Freundlich, with a capacity of 0.87 and $2.02 \mathrm{mmol} \mathrm{g}^{-1}$, respectively. The amine-modified mesoporous silica, $\mathrm{NH}_{2}-\mathrm{MCM}^{-48}$ for this study is a very high potential as an adsorbent of metal ions used in the study.
\end{abstract}

Keywords: Adsorption, 3-APTMS, Mesoporous Silica, Heavy Metals.

RASĀYAN J. Chem., Vol. 14, No.1, 2021

\section{INTRODUCTION}

Silver $(\mathrm{Ag})$ and chromium $(\mathrm{Cr})$ are heavy metals that can cause health problems to live organisms as well as damage the habitat and water ecosystem. Chromium (III) found in water can be converted to chromium (VI) which is toxic. ${ }^{1,2}$ If it accumulates in the body, it will cause cancer and genetic transmutation. For these reasons, it is necessary to reduce their concentration in the water environment. Several techniques have been reported for separating heavy metal ions from wastewater, such as ion exchange $^{2,3}$, precipitation ${ }^{4,5}$, membrane technology ${ }^{6,7}$, and adsorption. ${ }^{8-16}$ Adsorption is a method widely used because it is simple and effective. ${ }^{17}$ The adsorbents used can derive from natural sources or synthetic materials. The synthetic ones can be porous or non-porous materials. Porous materials are divided into microporous, mesoporous, and macroporous. Mesoporous substances are interesting to be used as adsorbents because they have high surface areas and large pore volumes.

One of the mesoporous materials is mesoporous silica (MCM-48), which belongs to an M41S family discovered by researchers from Mobil Oil Corporation. They are amorphous with well-defined pore shapes and sizes, have large specific surface areas and specific pore volumes. ${ }^{18,19}$ The mesoporous material, MCM-48, is more attractive as an adsorbent due to the cubic structure that produces threedimensional channels protecting the blockage of the pores by guest molecules and making it easier for the diffusion of molecules into the pores. ${ }^{20}$ Silanol and siloxane groups are usually found in the substance. They can interact with heavy metal ions. To increase the ability in adsorbing metal ions, modification of the surface of MCM-48 is a promising method because several modifying agents are available. One of the functional materials that are most frequently used to modify the kind of silica is 3-aminopropyltrimethoxysilane (3-APTMS).

Rasayan J. Chem., 14(1), 204-211(2021)

http://dx.doi.org/10.31788/ RJC.2021.1415963

This work is licensed under a CC BY 4.0 license. 
The current research of the modified silica has been utilized effectively as an adsorbent of heavy metal ions from aqueous solutions. ${ }^{11,21-23}$ Amino $\left(-\mathrm{NH}_{2}\right)$ group in 3-APTMS is a ligand of the hard base that can strongly interact with a hard acid such as Cr(III) ion. However, a previous study showed that the amino-functionalized MCM-48 interacted well with a borderline acid, $\mathrm{Cu}(\mathrm{II})$ ion. In this work, the adsorption of the soft acid, $\mathrm{Ag}(\mathrm{I})$ ion, on the amine-functionalized MCM-48 was conducted to compare the interaction of the material with other kinds of acids. As a comparison, the $\mathrm{Cr}$ (III) ion was also used as an adsorbate. Adsorption processes depend on $\mathrm{pH}$, contact time, and concentration; therefore, the adsorptions of $\mathrm{Ag}(\mathrm{I})$ and $\mathrm{Cr}(\mathrm{III})$ ions were studied under various $\mathrm{pH}$, contact time, and initial concentration. Results showed that $\mathrm{NH}_{2}-\mathrm{MCM}-48$ was a very promising adsorbent of the studied ions.

\section{EXPERIMENTAL}

\section{Material}

The materials used were cetyltrimethylammonium bromide (CTAB), Ludox HS-40 purchased from Du Pont, Triton X-100, 3-aminopropyltrimethoxysilane (3-APTMS) from Sigma-Aldrich, base ( $\mathrm{NaOH})$, acids $\left(\mathrm{HCl}\right.$ and $\left.\mathrm{CH}_{3} \mathrm{COOH}\right)$ as well as $\mathrm{AgNO}_{3}$ and $\mathrm{Cr}\left(\mathrm{NO}_{3}\right)_{3} \cdot 9 \mathrm{H}_{2} \mathrm{O}$ as the heavy metal sources. They were used directly used without any treatment.

\section{Synthesis of MCM-48 and Amine-modified MCM-48}

The synthesis of MCM-48 and the removal of surfactant from the as-synthesized MCM-48 followed the procedure mentioned in the previous study ${ }^{24}$ without the addition of $\mathrm{NaCl}$. The XRD patterns of materials before and after the removal of surfactant (template) were obtained by using a diffractometer (Siemens D500), using $\mathrm{CuK} \alpha$ as a source of radiation with a wavenumber of $1.5412 \AA$. Samples were placed into an aluminum holder and the diffraction patterns were created in a continuous scan mode (a scan rate $=1$ degree 2 -theta $/ \mathrm{min}$ and a step size $=0.02$ degree 2 -theta). The divergence slit was $0.3^{\circ}$ and the receiving slit was $0.05^{\circ}$. The experiments were conducted at a current of $30 \mathrm{~mA}$, an accelerating voltage of $40 \mathrm{kV}$, and a scan range from 0.8 to 10 degree 2-theta. The FTIR spectra of samples were obtained using a Shimadzu (IR Prestige-21 FTIR Spectrometer) run on 340-4500 $\mathrm{cm}^{-1}$ at a resolution of 4 , and a scan number of 300 . Modification of MCM-48 was conducted following the previous method ${ }^{25}$ with some adjustment as has been described elsewhere. ${ }^{11}$

\section{Experiments of Adsorption Kinetics}

Adsorption kinetic experiments of $\mathrm{Ag}(\mathrm{I})$ and $\mathrm{Cr}(\mathrm{III})$ ions by $\mathrm{NH}_{2}-\mathrm{MCM}-48$ were separately studied using silver nitrate and chromium(III) nitrate solutions with the same initial concentrations of $\mathrm{Ag}(\mathrm{I})$ and $\mathrm{Cr}(\mathrm{III})$ ions $(100 \mathrm{mg} / \mathrm{L})$. The adsorbent used was $100 \mathrm{mg}$ added to $50 \mathrm{~mL}$ of the ion solutions and stirred at ambient temperature for times ranging from 10 to 90 minutes for $\mathrm{Ag}(\mathrm{I})$ ion and 360 to 1260 minutes for $\mathrm{Cr}$ (III) ion on a magnetic stirrer (stirring rate was similar). Filtering removes the solids from the solution, and an atomic absorption spectrophotometer examined the filtrates containing the ions. These experiments can also obtain the optimum contact times of $\mathrm{Ag}(\mathrm{I})$ and $\mathrm{Cr}(\mathrm{III})$ ions. Experiments without any adsorbent were conducted as control experiments. The pseudo-first-order or pseudo-second-order kinetics were used extensively to describe the adsorption kinetics used. The pseudo-first-order model can be seen in equation (1), derived by Azizian. ${ }^{26}$

$$
\ln \left(q_{e}-q_{t}\right)=\ln q_{e}-k_{l} t
$$

The numbers of ions adsorbed at equilibrium and at time $t$ are $q_{e}$ and $q_{t}$, respectively and the rate constant of the pseudo-first-order is $k_{l}$.

The pseudo-second-order process is shown in equation (2),

$$
\frac{t}{q_{t}}=\frac{1}{k_{2} q_{e}^{2}}+\frac{t}{q_{e}}
$$

Where $q_{e}$ and $q_{\mathrm{t}}$ are the numbers of ions adsorbed at equilibrium and at time $t$, respectively and $k_{2}$ is the rate constant of the pseudo-second-order process. ${ }^{26}$

\section{Adsorption of $\mathbf{A g}(\mathrm{I})$ and $\mathrm{Cr}(\mathrm{III})$ Ions As A Function of pH}

The adsorption of $\mathrm{Ag}(\mathrm{I})$ and $\mathrm{Cr}(\mathrm{III})$ ions at various initial $\mathrm{pH}$ (2-7) was conducted to study the influence of $\mathrm{pH}$ on the adsorption process. Solutions used to adjust the initial $\mathrm{pH}$ were $\mathrm{HCl}$ and $\mathrm{NaOH}$. The $\mathrm{pH}$ adjustment was carried out before the addition of the adsorbent. The experiments were performed at the optimum contact time and the blank experiments without the addition of adsorbent at each $\mathrm{pH}$ value were also conducted. 


\section{Adsorption of $\mathbf{A g ( I )}$ and $\mathbf{C r}(\mathrm{III})$ Ions As A Function of the Initial Concentration of Ions}

The adsorption of $\mathrm{Ag}(\mathrm{I})$ and $\mathrm{Cr}(\mathrm{III})$ ions at various initial concentrations was performed to investigate the effect of concentration on adsorption. The procedure was conducted by mixing the ion solutions with $\mathrm{NH}_{2}$-MCM-48 (100 mg) in a beaker containing $50 \mathrm{~mL}$ of a single metal ion solution, carried out at the optimum contact time and $\mathrm{pH}$. The experiments were performed at a concentration range of 100$800 \mathrm{mg} / \mathrm{L}$.

\section{Characterization of MCM-48 Materials}

\section{RESULTS AND DISCUSSION}

The X-ray diffraction patterns of MCM-48 before and after removing surfactants are given in Fig.- 1 . The XRD pattern (Fig.-1a) shows the presence of 2-theta with high intensities at $2.21^{\circ}$ and $2.44^{\circ}$ with the Müller indexes of [211] and [220], respectively. Several peaks; [220], [321], [400], [420], [322], [422], and [321] are observed with low intensities. The peaks are specific of material with the good order of MCM-48 as described in previous works. ${ }^{18,19,27}$ After the removal of the template, all peaks shift to higher 2-theta due to constriction and condensation of the pores. The intensities of peaks increase after the removal of surfactants because of the absence of scattering caused by the template.

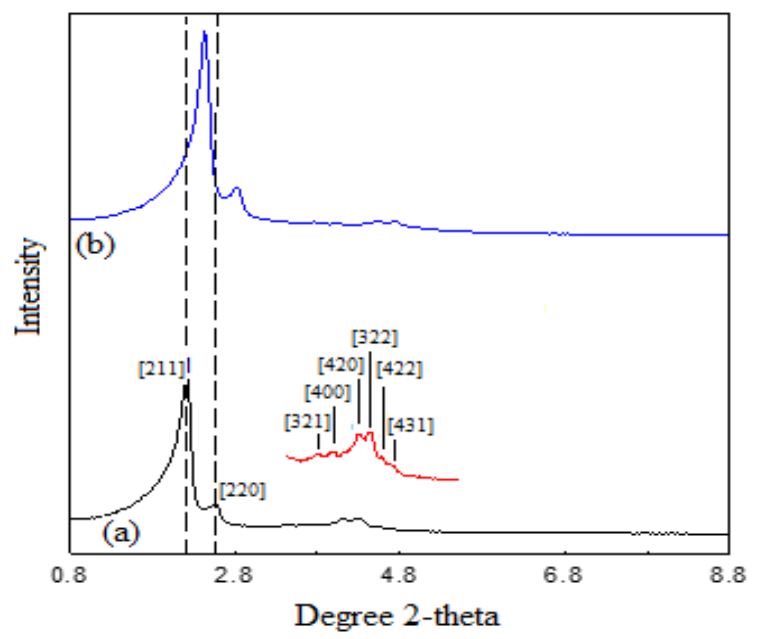

Fig.-1: XRD Patterns of MCM-48 (a) Before and (b) After Removal of the Template

Functional groups found in MCM-48 before and after extraction of surfactants as well as after modification $\left(\mathrm{NH}_{2}-\mathrm{MCM}-48\right)$ have been reported in the previous study. ${ }^{11}$ After the removal of the surfactant from MCM-48, almost all surfactants have been removed. After modification, there was an interaction between silanol groups and 3-APTMS shown by the presence of - $\mathrm{C}-\mathrm{H},-\mathrm{N}-\mathrm{H},-\mathrm{C}-\mathrm{N}$, and Si$\mathrm{CH}_{2}-\mathrm{R}$ obtained from 3-APTMS. The FTIR spectra of modified MCM-48 with and without $\mathrm{Ag}(\mathrm{I})$ and $\mathrm{Cr}(\mathrm{III})$ ions are given in Fig.-2.
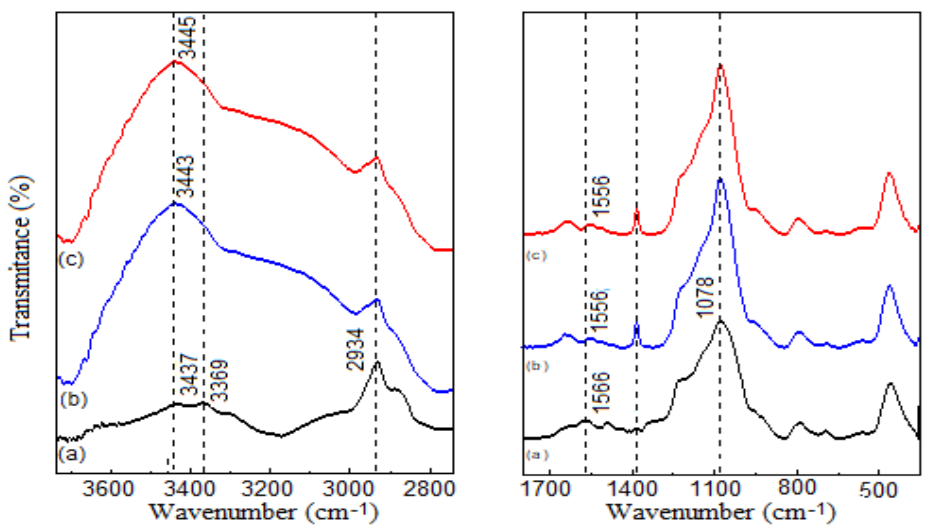

Fig.-2: FTIR Spectra of (a) NH2-MCM-48, (b) NH2-MCM-48 + Ag(I) and c) NH2-MCM-48 + Cr(III)

The peaks at 3432 and $3368 \mathrm{~cm}^{-1}$ associated with the stretching $-\mathrm{N}-\mathrm{H}$ vibration are unified and shift to 3443 and $3445 \mathrm{~cm}^{-1}$ after adsorption of $\operatorname{Ag}(\mathrm{I})$ and $\mathrm{Cr}(\mathrm{III})$ ions, respectively. This finding showed that the ions interacted with the $-\mathrm{NH}_{2}$ group on the surface of the modified MCM-48. The fact is supported by the decrease in the $-\mathrm{N}-\mathrm{H}$ bending intensity at $1566 \mathrm{~cm}^{-1}$ caused by the interaction of ions with $-\mathrm{NH}_{2}$ 
groups through electron-pair donors from the nitrogen atom in the amino group. The absorption peak of the vibration also shifts to $1556 \mathrm{~cm}^{-1}$ after the interaction with $\mathrm{Ag}(\mathrm{I})$ and $\mathrm{Cr}(\mathrm{III})$ ions. Also, the intensity of the absorption band at a wavenumber of $1385 \mathrm{~cm}^{-1}$ increases because the interaction of the ions with the $-\mathrm{NH}_{2}$ groups can cause the increase of the polarity of $\mathrm{NH}_{2}-\mathrm{MCM}-48 .{ }^{11}$ The SEM images of $\mathrm{NH}_{2}-\mathrm{MCM}-48$ before and after adsorption of $\mathrm{Cr}(\mathrm{III})$ and $\mathrm{Ag}(\mathrm{I})$ ions are given in Fig.-3.

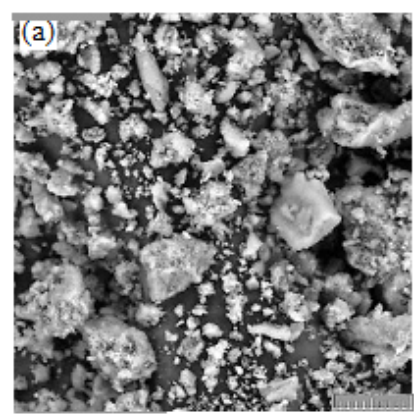

$50 \mu \mathrm{m}$
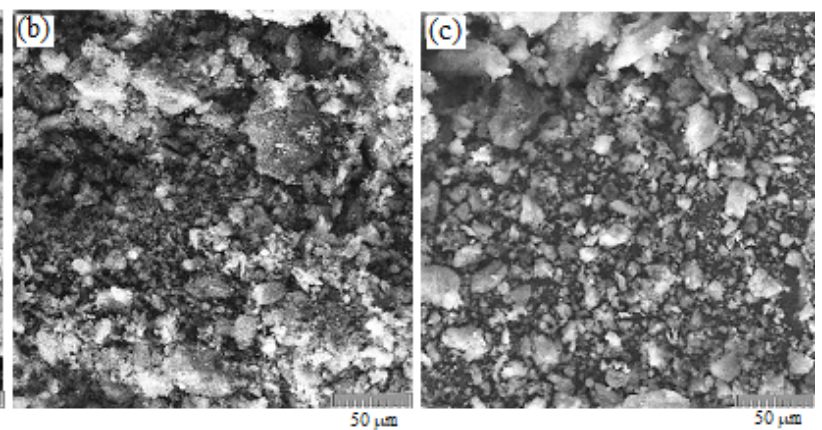

Fig.-3: SEM Images of $\mathrm{NH}_{2}-\mathrm{MCM}-48$ (a) Before Adsorption, (b) After Adsorption of Ag(I) Ion and (c) After Adsorption of $\mathrm{Cr}$ (III) Ion

The SEM images show that $\mathrm{NH}_{2}-\mathrm{MCM}-48$ consist of particles ranging from several to dozens of micrometers, and gives an irregular shape with a relatively smooth surface. After adsorption of $\mathrm{Ag}(\mathrm{I})$ and $\mathrm{Cr}(\mathrm{III})$ ions, there is agglomeration on the surface of the adsorbent caused by the metal ions adsorbed.

\section{The Kinetic Study and the Adsorption Optimum Time}

The adsorption of $\mathrm{Ag}(\mathrm{I})$ and $\mathrm{Cr}(\mathrm{III})$ ions on $\mathrm{NH}_{2}-\mathrm{MCM}-48$ as a function of the contact time is given in Fig.-4. The adsorption of ions increases with increasing contact time. The maximum adsorbed amount is achieved when the equilibrium is reached at the optimum time. The optimum times for the adsorption of $\operatorname{Ag}(\mathrm{I})$ and $\mathrm{Cr}(\mathrm{III})$ ions are 20 and $900 \mathrm{~min}$, respectively. The contact times were applied for experiments at various $\mathrm{pH}$ and concentrations.
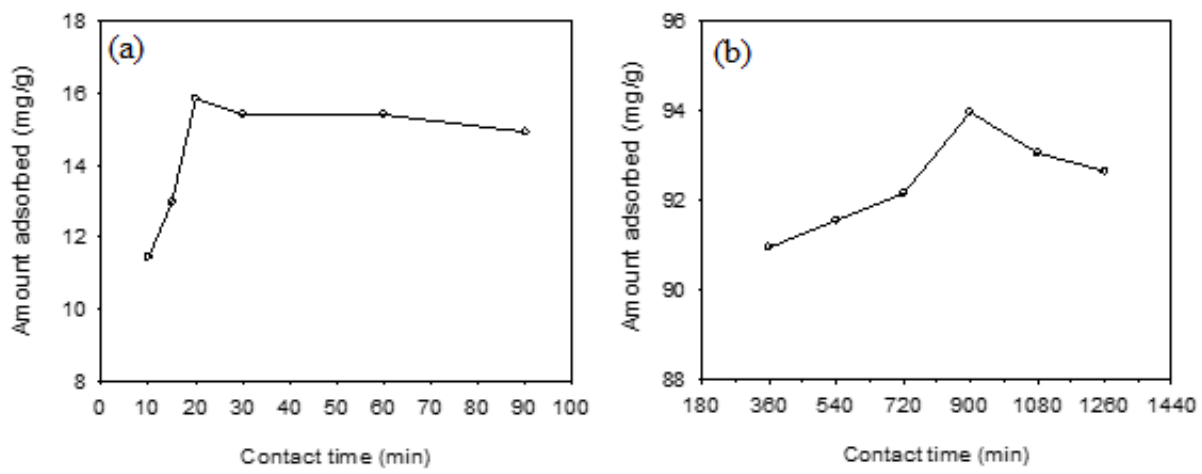

Fig.-4: Effect of Contact Time on Quantity (a) $\mathrm{Ag}(\mathrm{I})$ and (b) $\mathrm{Cr}$ (III) Ions Adsorbed on $\mathrm{NH}_{2}-\mathrm{MCM}-48$

The kinetic data can be obtained from the amount of ions adsorbed at various contact times as given in Table 1. The correlation coefficients using the first-pseudo-order equation are far from 1 . However, the correlation coefficients using the second-pseudo-order equation are close to one. Also, the amount of ions adsorbed at the equilibrium obtained from the second-order equation is closer to that obtained from experiments. The results indicate that the adsorption of $\mathrm{Ag}(\mathrm{I})$ and $\mathrm{Cr}(\mathrm{III})$ ions are in parallel with the pseudo-second-order equation. The same results were also reported by other studies. ${ }^{11,26}$ The rate constants $\left(k_{2}\right)$ of $\operatorname{Ag}(\mathrm{I})$ and $\mathrm{Cr}(\mathrm{III})$ adsorption in this study are $1.0 \times 10^{-24}$ and $1.0 \times 10^{-3} \mathrm{~g} \mathrm{mg} \mathrm{min}{ }^{-1}$, respectively. These results are following the results of the optimum contact time, where the optimum contact time for the adsorption of $\mathrm{Ag}$ (I) is lower than the adsorption of $\mathrm{Cr}$ (III).

Table-1: Kinetic Data of $\mathrm{Ag}(\mathrm{I})$ and $\mathrm{Cr}(\mathrm{III})$ Ions adsorbed on MCM-48- $\mathrm{NH}_{2}$

\begin{tabular}{c|c|c}
\hline Data & $\operatorname{Ag}(\mathrm{I})$ & $\operatorname{Cr}(\mathrm{III})$ \\
\hline Pseudo-first-order & & \\
\hline$k_{l}\left(\mathrm{~min}^{-1}\right)$ & 0.01 & 0.001 \\
\hline
\end{tabular}


Vol. 14 | No. 1 |204-211| January - March | 2021

\begin{tabular}{c|c|c}
\hline$q_{e}\left(\mathrm{mg} \mathrm{g}^{-1}\right)$ & 2.5 & 4.24 \\
\hline $\mathrm{R}^{2}$ & 0.38 & 0.72 \\
\hline Linear equation & $\mathrm{y}=-0.0057 \mathrm{x}+0.3978$ & $\mathrm{y}=-0.0005 \mathrm{x}+0.6269$ \\
\hline Pseudo-second-order & & \\
\hline$k_{2}\left(\mathrm{~g} \mathrm{mg}^{-1} \mathrm{~min}^{-1}\right)$ & 0.02 & 0.001 \\
\hline$q_{e}\left(\mathrm{mg} \mathrm{g}^{-1}\right)$ & 14.37 & 94.34 \\
\hline $\mathrm{R}^{2}$ & 0.94 & 0.99 \\
\hline Linear equation & $\mathrm{y}=0.0696 \mathrm{x}-0.3014$ & $\mathrm{y}=0.0106 \mathrm{x}+0.1154$ \\
\hline $\begin{array}{c}\text { Experimental } q_{e}(\mathrm{mg} \\
\left.\mathrm{g}^{-1}\right)\end{array}$ & 15.84 & 93.96 \\
\hline
\end{tabular}

\section{The optimum pH of Adsorption}

Figure-5 shows the adsorption of $\mathrm{Ag}(\mathrm{I})$ and $\mathrm{Cr}(\mathrm{III})$ ions on $\mathrm{NH}_{2}-\mathrm{MCM}-48$ as a function of the $\mathrm{pH}$ of the solution ranging from 2 to 7 . The amount of $\mathrm{Ag}(\mathrm{I})$ and $\mathrm{Cr}(\mathrm{III})$ ions adsorbed on $\mathrm{NH}_{2}-\mathrm{MCM}-48$ increases steeply from a $\mathrm{pH}$ of 2 to 3 for both ions. After that, a small increase in the adsorption is observed from $\mathrm{pH} 3$ to 4 for $\mathrm{Ag}(\mathrm{I})$ ion and the gradual decrease occurs from the $\mathrm{pH}$ of 4 to 7 . The adsorption of $\mathrm{Ag}(\mathrm{I})$ ion reaches a maximum of $50.28 \mathrm{mg} \mathrm{g}^{-1}$ at a $\mathrm{pH}$ of 4 . Other researchers also reported the same optimum $\mathrm{pH} \cdot{ }^{10,27,28}$ For $\mathrm{Cr}(\mathrm{III})$ ion, the amount adsorbed increases from $\mathrm{pH}$ of 4 to 5 and then from $\mathrm{pH}$ of 5 to 7, the amount adsorbed decreases gradually. Thus, the adsorption of $\mathrm{Cr}$ (III) achieves a maximum at a $\mathrm{pH}$ of 5 . The same result was also reported elsewhere. ${ }^{29}$
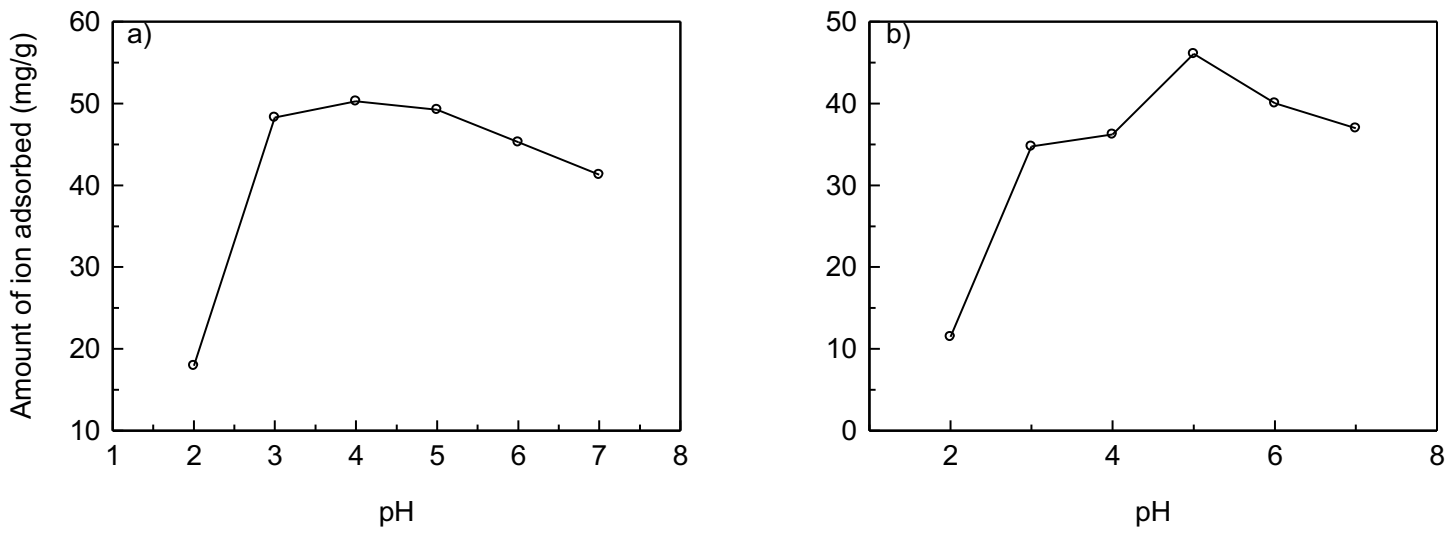

Fig.-5: The Effect of $\mathrm{pH}$ on the Adsorption of (a) $\mathrm{Ag}(\mathrm{I})$ and (b) $\mathrm{Cr}$ (III) Ions on $\mathrm{NH}_{2}-\mathrm{MCM}-48$

The low adsorption of ions on the adsorbent at low $\mathrm{pH}$ is because of the higher concentration of $\mathrm{H}^{+}$in the solution that competes with the ions for the adsorption sites. Also, the protonation of the surface of $\mathrm{NH}_{2}-\mathrm{MCM}-48$ to form $\mathrm{H}_{3} \mathrm{~N}^{+}-\mathrm{MCM}-48$ can inhibit the ability of the functional groups of the adsorbents to interact with the ions. At higher $\mathrm{pH}$, the amount of ions adsorbed is higher because the protonated surface is lower, causing the higher negative charge on the surface, to enhance the adsorption. Further increasing of $\mathrm{pH}$ (at very high $\mathrm{pH}$ ), precipitation of metal hydroxide occurred resulting in the lower concentration of ions detected in solutions. From the results, it is clear that the optimum $\mathrm{pH}$ of $\mathrm{Ag}(\mathrm{I})$ and $\mathrm{Cr}$ (III) ions are 4 and 5, respectively. The optimum $\mathrm{pH}$ was used for studying the effect of concentrations to find the adsorption capacity.

\section{Adsorption Isotherms}

The adsorption of $\operatorname{Ag}(\mathrm{I})$ and $\mathrm{Cr}(\mathrm{III})$ ions is enhanced by increasing the initial concentration of the ions solutions. To determine the adsorption capacity, Langmuir and Freundlich's isotherms were used as can be seen in Fig.-6. Table-2 shows that the adsorption of $\mathrm{Ag}(\mathrm{I})$ and $\mathrm{Cr}(\mathrm{III})$ ions fit better Langmuir isotherm with the $\mathrm{R}^{2}$ value that closer to one. Some researchers also reported the same result. ${ }^{29,30}$ For comparison, data from a previous study are also given in Table- 2 .

Table-2 shows the ions adsorbed on the modified material are in the order of $\mathrm{Cr}(\mathrm{III})>\operatorname{Ag}(\mathrm{I})>\mathrm{Zn}(\mathrm{II})>\mathrm{Cu}(\mathrm{II})$. The adsorption capacity $\left(\mathrm{Q}_{\mathrm{o}}\right)$ obtained from the Langmuir equation was $2.02 \mathrm{mmol} \mathrm{g}^{-1}$ for $\mathrm{Cr}$ (III) ion and $0.87 \mathrm{mmol} \mathrm{g}^{-1}$ for $\mathrm{Ag}(\mathrm{I})$ ion. The adsorption capacity of the former ion is higher than that of the later. This finding is consistent with the HSAB principle. According to this principle, hard Lewis acids such as $\mathrm{Cr}(\mathrm{III})$ will interact well with hard Lewis bases such as $-\mathrm{NH}_{2}$ group from 3-APTMS. The previous studies used borderline Lewis acids, $\mathrm{Cu}(\mathrm{II})$ and $\mathrm{Zn}(\mathrm{II}) .{ }^{11,31}$ 

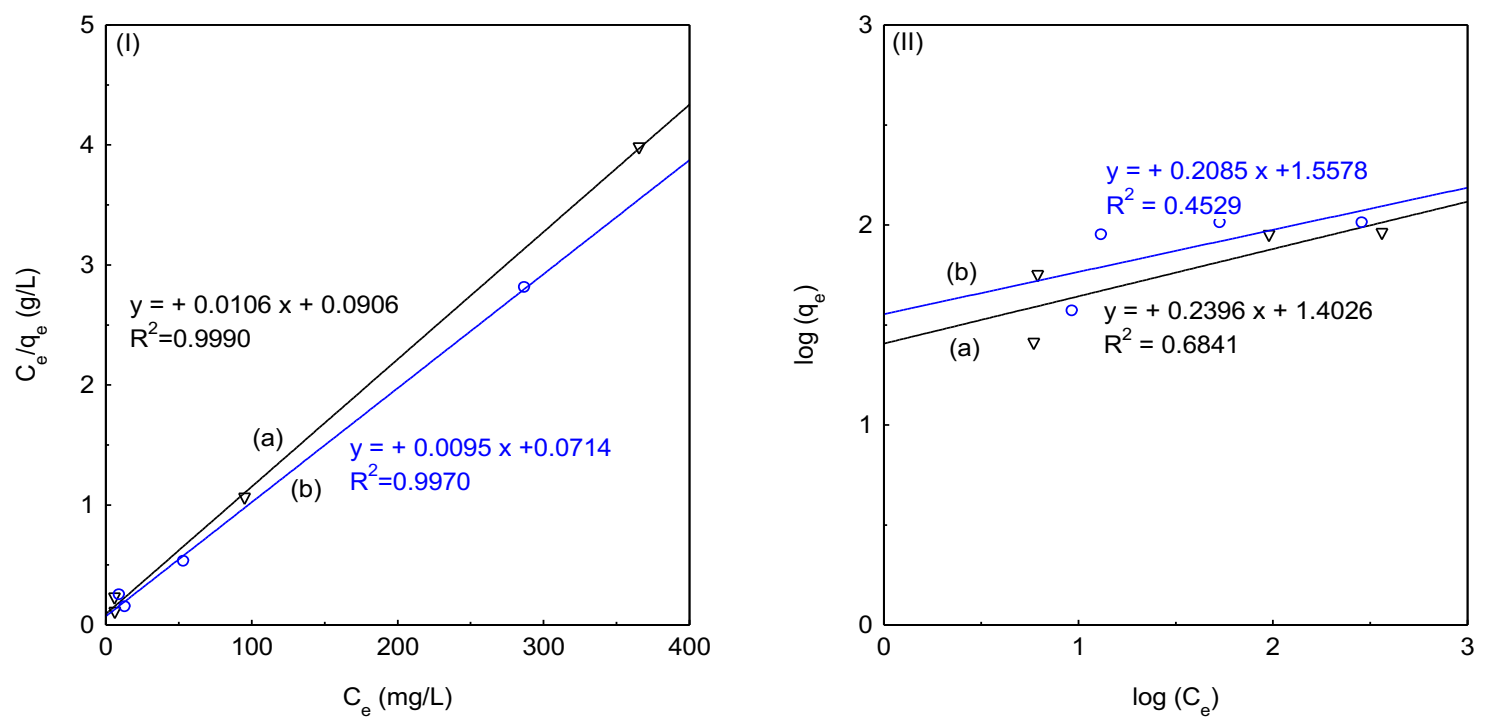

Fig.-6: Isotherms of (I) Langmuir and (II) Freundlich for Adsorption of (a) $\mathrm{Ag}$ (I) and (b) $\mathrm{Cr}$ (III) Ions.

Table-2: The Constants of Freundlich and Langmuir Models for the Metal Ions Adsorption on $\mathrm{NH}_{2}-\mathrm{MCM}-48$

\begin{tabular}{c|c|c|c|c|c|c|c|c}
\hline \multirow{2}{*}{ Ions } & \multicolumn{3}{|c|}{ Langmuir Model } & \multicolumn{4}{c|}{ Freundlich Model } \\
\cline { 2 - 9 } & \multicolumn{2}{|c|}{$\mathrm{Q}_{\mathrm{o}}$} & $\mathrm{b}$ & $\mathrm{R}^{2}$ & \multicolumn{2}{|c}{$\mathrm{K}_{\mathrm{f}}$} & $\mathrm{n}$ & $\mathrm{R}^{2}$ \\
\cline { 2 - 9 } & $\mathrm{mg} \mathrm{g}^{-1}$ & $\mathrm{mmol} \mathrm{g}^{-1}$ & & & $\mathrm{mg} \mathrm{g}^{-1}$ & $\mathrm{mmol} \mathrm{g}^{-1}$ & & \\
\hline $\mathrm{Cr}(\mathrm{III})$ & 105.26 & 2.02 & 0.14 & 0.99 & 35.12 & 0.69 & 4.79 & 0.45 \\
\hline $\mathrm{Ag}(\mathrm{I})$ & 93.43 & 0.87 & 0.12 & 0.99 & 25.26 & 0.23 & 4.17 & 0.68 \\
\hline $\mathrm{Cu}(\mathrm{II})^{11}$ & 25.45 & 0.43 & 0.07 & 0.98 & 11.89 & 0.20 & 8.79 & 0.94 \\
\hline $\mathrm{Zn}(\mathrm{II})^{31}$ & 35.71 & 0.56 & 0.03 & 0.99 & 5.68 & 0.09 & 3.18 & 0.98 \\
\hline
\end{tabular}

The higher adsorption capacity of $\operatorname{Ag}(\mathrm{I})$ ion compared to the borderline Lewis acid is likely caused by the higher the ionic radius of $\mathrm{Ag}(\mathrm{I})(126 \mathrm{pm})$ than that of the two ions ( $\mathrm{Zn}$ (II) $=74 \mathrm{pm}$ and $\mathrm{Cu}(\mathrm{II})=73 \mathrm{pm}$ ). According to the previous study, the amount of ions adsorbed is directly proportional to the ionic radius. ${ }^{32}$ Table-3 shows the comparison of the adsorption capacity of ions used in this study and the ones from other researchers.

Table-3: Adsorption Capacities of Cr(III) and Ag(I) Ions on Several Adsorbents

\begin{tabular}{c|c|c|c|c}
\hline \multirow{2}{*}{ Adsorbents } & \multicolumn{2}{c}{$\begin{array}{c}\text { Adsorption } \\
\text { Capacity (mg/g) }\end{array}$} & \multicolumn{2}{c}{ Optimum pH } \\
\cline { 2 - 5 } & $\mathrm{Cr}(\mathrm{III})$ & $\mathrm{Ag}(\mathrm{I})$ & $\mathrm{Cr}(\mathrm{III})$ & $\mathrm{Ag}(\mathrm{I})$ \\
\hline Cr(III) ionic imprinting PVA/SA & & 6 & \\
\hline Jackfruit peel modified by EDTA & 59.91 & & 5 & \\
\hline $\begin{array}{c}\text { Amino functionalized mesoporous nanofiber } \\
\text { membrane }^{33}\end{array}$ & 91.67 & & - & \\
\hline $\begin{array}{c}\text { Fe-doped Biomass-derived ordered mesoporous } \\
\text { carbon }^{35}\end{array}$ & 46 & & 6 & \\
\hline $\begin{array}{c}\text { Mesoporous silica functionalized with 3- } \\
\text { mercaptopropyl trimethoxysilane }\end{array}$ & & 114.9 & & 4 \\
\hline $\begin{array}{c}\text { Chitosan/polydopamine@C@magnetic fly ash } \\
\text { (36 }\end{array}$ & & 57.02 & & 4 \\
\hline $\begin{array}{c}\text { Poly(vinyl alcohol) modified with thiourea (TU- } \\
\text { PVA) }\end{array}$ & & 66.93 & & 5 \\
\hline $\begin{array}{c}\text { Amine-functionalized mesoporous silica (this } \\
\text { study) }\end{array}$ & 105.26 & 93.43 & 5 & 4 \\
\hline
\end{tabular}

It can be seen that the adsorption capacity of the $\mathrm{Cr}(\mathrm{III})$ ion on $\mathrm{NH}_{2}-\mathrm{MCM}-48$ is higher than that on other adsorbents used by different researchers, except for the adsorption of the $\mathrm{Ag}(\mathrm{I})$ ion on mesoporous silica functionalized by 3 -mercaptopropyltrimethoxysilane. This occurred because the modified agents used for the formation of the two materials were different. The modified agent used in Ref. ${ }^{29}$ contains a sulfhydryl group which is a soft base. The base can interact well with a soft acid, such as $\mathrm{Ag}(\mathrm{I})$ ion. The findings in this study indicate that this material is a very promising adsorbents of metal ions. 


\section{CONCLUSION}

The study concluded that the amount of $\mathrm{Ag}(\mathrm{I})$ and $\mathrm{Cr}(\mathrm{III})$ ions adsorbed on $\mathrm{NH}_{2}-\mathrm{MCM}-48$ achieved a maximum at the contact time of 20 and $900 \mathrm{~min}$ and $\mathrm{pH}$ of 4 and 5, respectively. Both ion adsorptions fitted the pseudo-second-order in which the rate constant of $\mathrm{Ag}(\mathrm{I})$ adsorption was higher than $\mathrm{Cr}(\mathrm{III})$ adsorption. Both ion adsorptions followed the Langmuir isotherm. The adsorption capacity of the $\mathrm{Cr}$ (III) ion $\left(2.02 \mathrm{mmol} \mathrm{g}^{-1}\right)$ was higher than that of the $\mathrm{Ag}(\mathrm{I})$ ion $\left(0.87 \mathrm{mmol} \mathrm{g}^{-1}\right)$. FTIR data clearly showed that there was an interaction between the ions and the functional group of the adsorbent. The interaction of both ions with $\mathrm{NH}_{2}-\mathrm{MCM}-48$ caused the shift of the stretching vibration of $-\mathrm{N}-\mathrm{H}$ and the decrease of the bending $-\mathrm{N}-\mathrm{H}$ intensity as well as the increase of the $-\mathrm{C}-\mathrm{N}$ intensity.

\section{ACKNOWLEDGMENT}

It is our pleasure to acknowledge Kartini and Fibiyanty for their assistance in FTIR and AAS measurements. The authors also thank Sorina Popescu for her assistance in the SEM discussion.

\section{REFERENCES}

1. A. Basu, B. Saha, American Journal of Analytical Chemistry 1(1), 25(2010), DOI: 10.4236/ajac.2010.11003

2. T.M. Zewail, N.S. Yousef, Alexandria Engineering Journal, 54(1), 83(2015), DOI:10.1016/j.aej.2014.11.008

3. O. Tavakoli, V. Goodarzi, M.R. Saeb, N.M. Mahmoodi, R. Borja, Journal of Hazardous Materials, 334, 256(2017), DOI:10.1016/j.jhazmat.2017.04.023

4. F. Fu, L. Xie, B. Tang, Q. Wang, S. Jiang, Chemical Engineering Journal, 189-190, 283(2012), DOI:10.1016/j.cej.2012.02.073

5. H.L. Fan, S.F. Zhou, W.Z. Jiao, G.S. Qi, Y.Z. Liu, Carbohydrate Polymers, 174, 1192(2017), DOI:10.1016/j.carbpol.2017.07.050

6. M. Mondal, M. Dutta, S. De, Separation and Purification Technology, 188, 155(2017), DOI:10.1016/j.seppur.2017.07.013

7. H. Yezil, A.E. Tugtas, Science of the Total Environmental, 693, 133608(2019), DOI:10.1016/j.scitotenv.2019.133608

8. M. Martínez, N. Miralles, S. Hidalgo, N. Fiol, I. Villaescusa, J. Poch, Journal of Hazardous Materials, 133(1-3), 203(2006), DOI:10.1016/j.jhazmat.2005.10.030

9. B. Buhani, N. Narsito, N. Nuryono, E.S. Kunarti, Indonesian Journal of Chemistry, 9(2), 170(2010), DOI:10.22146/ijc.21176

10. A. Sari, M. Tüzen, Microporous and Mesoporous Materials, 170, 155(2013), DOI:10.1016/j.micromeso.2012.12.004

11. P. Taba, P. Budi, A.Y. Puspitasari, IOP Conference Series: Material Science Engineering 188, 012015(2017), DOI:10.1088/1757-899X/188/1/012015

12. J.L. Álvarez, M.J. Bastidas, L. Giraldo, P. Rodríguez-Estupiñán, J.C. Moreno-Piraján, RASĀYAN Journal of Chemistry, 11(2), 780 (2018), DOI:10.31788/RJC.2018.1122095

13. H.J. Rao, P. King, Y.P. Kumar, Rasayan Journal of Chemistry, 11(4), 1577(2018), DOI:10.31788/RJC.2018.1144024

14. R.E.K. Billah, Y. El yamani, Y. Rakhila, M. Agunaou, A. Soufiane, RASĀYAN Journal of Chemistry, 12(1), 347(2019), DOI:10.31788/RJC.2019.1215078

15. R. Mahalakshmi, K. Preethi, D. Kalaiselvi, M. Manjuladevi, Rasayan Journal of Chemistry, 12(1), 245(2019), DOI:10.31788/RJC.2019.1215001

16. H.L. Yadav, A. Jamal, Rasayan Journal of Chemistry, 10(3), 1062(2017), DOI:10.7324/RJC.2017.1031775

17. J. Cao, Y. Wu, Y. Jin, P. Yilihan, W. Huang, Journal of the Taiwan of Institute of Chemical Engineer, 45(3), 860(2014), DOI:10.1016/j.jtice.2013.09.011

18. V. Calvino-Casilda and R.M. Martín-Aranda, Catalysis Today, 354(1), 44(2020), DOI:10.1016/j.cattod.2019.06.046

19. C.T. Kresge, W.J. Roth, Chemical Society Reviews, 42(9), 3663(2013), DOI:10.1039/C3CS60016E

20. M. Anbia, S, Khoshbooei, Journal of Nanostructure in Chemistry, 5, 139(2015), DOI:10.1007/s40097-014-0145-7 
21. H. Faghihian, M. Naghavi, Separation Science and Technology, 49(2), 214(2014), DOI:10.1080/01496395.2013.819516

22. P. Dinh Du, N. T. Hieu, T.C. To, L.G. Bach, M.X. Tinh, T. Xuan Mau, D. Quang Khieu, Advances in Materials Science and Engineering, 2019, 1(2019), DOI:10.1155/2019/8573451

23 Q. Yuan, N. Li, Y. Chi, W. Geng, W. Yan, Y. Zhao, X. Li, B. Dong, Journal of Hazardous Materials, 254-255, 157(2013), DOI:10.1016/j.jhazmat.2013.03.035

24. P. Taba, Makara Journal of Science, 12(2), 120(2008), DOI:10.22146/ijc.21503

25. T.D. Batueva, N.B. Kondrashova, M.G. Shcherban, Inorganic Materials, 56(4), 360(2020), DOI:10.1134/S0020168520040020

26. Y. Huang, M.U. Farooq S. Lai, X. Feng, P. Sampranpiboon, X. Wang, W. Huang, AIChE Journal, 64(5), 1793(2018), DOI:10.1002/aic.16051

27. D. Hua, S. Chen, Z. Zhou, A. Chen, R. Li, Journal of Fuel Chemistry and Technology, 40(5), 564(2012), DOI:10.1016/S1872-5813(12)60023-1

28. G.M. Al-Senani, F.F. Al-Fawzan, Egyptian Journal of Aquatic Research, 44(3), 187(2018), DOI:10.1016/j.ejar.2018.07.006

29. U. Pongkitdachoti, F. Unob, Journal of Environmental Chemical Engineering, 6(1), 596(2018), DOI:10.1016/j.jece.2017.12.046

30. J. H. Chen, G.P. Li, Q.L. Liu, J.C. Ni, W.B. Wu, J.M. Lin, Chemical Engineering Journal, 165(2), 465(2010), DOI:10.1016/j.cej.2010.09.034

31. P. Taba, R.D.P. Mustafa, M. Ramang, A.H. Kasim, IOP Conference Series: Journal of Physics: Conference Series, 979, 012058 1234567890(2018), DOI:10.1088/1742-6596/979/1/012058

32. R. Javed, L.A. Shah, M. Sayeda, M.S. Khan, RSC Advances, 27, 14787(2018), DOI:10.1039/C8RA00578H

33. S.H. Ranasinghe, A.N. Navaratne, N. Priyantha, Journal of Environmental Chemical Engineering, 6(5), 5670 (2018), DOI:10.1016/j.jece.2018.08.058

34. A.A. Taha, J. Qiao, F. Li, B. Zhang, Journal of Environmental Science, 24(4), 610(2012), DOI:10.1016/S1001-0742(11)60806-1

35. K. Li, Y. Zhou, J. Li, Y. Liu, Journal of the Taiwan Institute of Chemical Engineers, 82, 312(2018), DOI:10.1016/j.jtice.2017.10.036

36. C. Mu, L. Zhang, X. Zhang, L. Zhong, Y. Li, Journal of Hazardous Materials, 381, 120943(2020), DOI:10.1016/j.jhazmat.2019.120943

37. T. Yang, L. Zhang, L. Zhong, X. Han, S. Dong, Y. Li, Hydrometallurgy, 175, 179(2018), DOI:10.1016/j.hydromet.2017.11.007

[RJC-5963/2020] 